\title{
Penyengat Island Halal Tourism Within the Framework of Local Wisdom
}

\author{
Riska Destiana $^{1}$, Tri Yuniningsih ${ }^{2}$, Ardiansyah $^{3}$ \\ \{Email: destiana.riska1812@gmail.com ; triyuniningsih67@yahoo.com\} \\ ${ }^{1}$ Student of Master Public Administration Faculty of Social and Political Sciences \\ Diponegoro University \\ ${ }^{2}$ Lecturers of the Department of Public Administration, Faculty of Social and Political \\ Sciences Diponegoro University
}

\begin{abstract}
Halal tourism development must be in line with respect for socio-cultural values and local wisdom. The Malay tribe, which is synonymous with Islam, is a major force for the development of halal tourism on Penyengat Island. Cultural, historical and religious tourism is the main attraction for the development of halal tourism on Penyengat Island, which of course involves the role of the local cultural community. This study aims to analyze the role of the cultural community in the development of halal tourism on Penyengat Island. This study uses a descriptive qualitative approach, through interviews and literature studies with data sources derived from informant interviews, journal articles and data related to the theme of the article. The Riau Islands LAM gave the idea that halal tourism should be built following the rules of Malay customs. The Aksi Bangun Negeri Foundation contributed to the preservation of Malay cultural values through the Penyengat Island movement to UNESCO world heritage by exploring the special values of Penyengat Island, namely outstanding local value, outstanding national value, outstanding regional value, and outstanding international value. The Indera Sakti Island Penyengat Cultural Foundation contributed to the preservation of Malay culture in terms of saving the ancient Riau manuscripts . The suggestions given are to increase the role of the cultural community in creating tour packages containing local Muslim identities and optimizing the application of Malay culture and customs in the lives of local communities.
\end{abstract}

Keywords : halal tourism, local wisdom, Malay culture, cultural community, Penyengat Island

\section{Introduction}

The Central Bureau of Statistics [1] released data on the number of foreign tourist arrivals to the Riau Islands Province, which increased in 2019. In the January-November 2019 period, foreign tourists to Indonesia reached 14,915,610 visits. Riau Islands Province ranked the second largest in Indonesia with three large percentage of tourist arrivals in JanuaryNovember 2019 including Bali (38,47 percent), Riau (17.37 per cent), Jakarta (15.21 per cent) and others ( 28.95 percent). Cumulatively for the January-November 2019 period, the number 
of foreign tourist visits to the Riau Islands Province reached 2,590,802 visits. That number exceeds the Medium Term Development Plan (Plan) Kepri \$ 2, 3 million tourists[19].

The tourism sector is one of the prima donna as a contributor to the country's foreign exchange. Various opportunities and tourism trends that are developing in the international world also influence the development of tourism in Indonesia. One of the tourism market opportunities that has been developing in recent years is halal tourism. Halal tourism is basically the application of the tourism industry with additional services aimed at meeting the needs of Muslim tourists who are traveling. Indonesia is the best halal tourism destination in the world in 2019 according to the 2019 Global Muslim Travel Index (GMTI). The Ministry of Tourism has appointed the Riau Islands Province to be one of the ten provinces to develop halal tourism in Indonesia. Strategic Design and Action Plan (DSRA) for the Development of Halal Tourism Destinations in Riau Islands Province 2018-2019 lists Penyengat Island as one of the leading areas for halal tourism development.

Tourism development must be based on conditions and carrying capacity with the aim of creating mutually beneficial long-term interactions between the achievement of tourism development goals, improving the welfare of local communities, and sustainable environmental carrying capacity in the future [2] . Tourism development must not marginalize community culture and local spirits. Therefore it is necessary to design tourism development that is in line with the development of culture and society. Globalization is a strong reason for the revival of local cultural identities in various parts of the world. This is also in line with what was conveyed by Anthony Gidde $\mathrm{n}$ [3] that the more homogeneous people's lifestyles are due to globalization, the stronger the people's dependence on deeper values that are believed to be such as religion, art, culture, literature, social institutions, customs and so on. Likewise, from a local perspective, when the world grows more homogeneous, we will appreciate the traditions that emerge from within. Without realizing it, the strategic value of local culture has inspired various regions to develop local potential in tourism development in Indonesia

Likewise, in fact, the development of halal tourism must be in line with local wisdom. Mahardika [4] states that the opinion of the Ministry of Tourism and the National Sharia Council-Indonesian Ulama Council states that sharia tourism has the following standard criteria: oriented towards the general benefit; oriented to enlightenment, refreshment and serenity; avoid polytheism and khurofat; avoid immorality, such as adultery, pornography, porno-action, liquor, drugs and gambling; maintaining human behavior, ethics and noble values, such as not being hedonistic and immoral; maintain trust, safety and comfort; universal and inclusive; preserving the environment; as well as respecting socio-cultural values and local wisdom. Local wisdom is one of the important things in the development of halal tourism.

Penyengat Island is a pilot project for the development of halal tourism in the Riau Islands Province. This island has great potential to become a leading destination with a rich cultural heritage from the Riau-Lingga Kingdom, which makes cultural tourism and religious tourism a mainstay product of Penyengat Island tourism development. The Malay tribe, which is synonymous with Islam, has become one of the main forces for the development of halal tourism on Penyengat Island. The cultural values and customs of the Malays that still live on Penyengat Island until now coexist with the religious life of the majority Muslim community. As an area that is full of cultural values, local wisdom is a special selling point for Penyengat Island tourist attraction.

Qadariyah [5] explains that the concept of tourism based on local wisdom applied in Sumenep Regency is quite relevant to the principles of sharia tourism, although it must also be admitted that in its implementation there are still some parts that have not been touched by Islamic values. The value of local wisdom in an area can be in line with the development of 
halal tourism with its priority on sharia principles in every element of the tourism industry. One form of involvement of customary law communities through the Indigenous Peoples Institution (LMA) is an effort to maintain local wisdom that has grown and rooted in local communities [6] .

Destiana's research [7] states that there are several cultural communities that play a role in the development of halal tourism destinations on Penyengat Island, namely the Riau Islands Customary Institution (LAM), the Indera Sakti Foundation and the Aksi Bangun Negeri Foundation. Culture and customs which are one of the sources of local wisdom provide rapid development in the tourism industry with intercultural understanding and understanding through the interaction of tourist visitors with local communities where the tourist area is located [8]. Therefore in this study will be analyzed on the role of cultural communities are in the development of halal tourism on the island Biting based on local wisdom.

\subsection{Literature Review}

\section{Halal Tourism}

Battour [9] concluded that halal tourism is all tourist objects or actions that are permitted according to Islamic teachings to be used by Muslim tourists in the tourism industry. This definition considers Islamic law as the basis for distributing tourism products and services to target consumers who are mostly Muslim, such as halal hotels, halal resorts, halal restaurants and halal travel. The definition also claims that tourist locations are not only in Muslim-majority countries. Therefore, halal tourism includes tourism services and products designed for Muslim tourists in Muslim and non-Muslim countries. What's more, the definition considers tourist destinations not only about religion, but other general tourism motivations.

Razzaq et.al [10] mentioned several concepts regarding halal tourism in their publication, one of which is Battour et.al which states that Muslim tourists tend to choose Sharia accommodation which has attributes such as the availability of halal food, the appropriateness of hotel staff uniforms, the absence of pictures. with pornographic content, the absence of alcoholic drinks, information on the closest mosque for Friday prayers, a meeting room that accommodates worship needs. The phenomenon of increasing demand for commercial tourism and hospitality services adhering to Islamic law is described as "halal tourism", "halal hospitality", "sharia tourism" or "Islamic tourism " [10] .

The definition of halal tourism must be seen from various aspects. From the various definitions above, it can be concluded that halal tourism is a tourism concept that offers additional services, in the form of meeting the basic needs of Muslims, on the basis of its implementation based on Islamic teachings. Emphasis on the concept of offering additional services means that halal tourism is not only about religious tourism, but covers the whole concept of tourism in general. Even though the main target is Muslim tourists, the manager of the halal tourism industry must be able to innovate by offering tourist attractions so that nonMuslim tourists have an interest in coming to a destination. This makes the concept of halal tourism actually broadens the target of tourist visits, because of the convenience offers for Muslim tourists in destination tourist destinations.

\section{Local culture}

Local wisdom is a set of knowledge along with certain values and norms derived from the adaptation and life experiences of a group of people in a certain location which then provides a form of thought patterns and certain actions as a way to live in harmony with their environment, with each other, and with themselves. himself [11]. Local wisdom can be in the form of tangible 
(textual, architectural, traditional artwork) and intangible (value system, kidung, advice), and in terms of types of local wisdom consists of governance, value systems, procedures, and special provisions such as sensitive areas and areas / holy building [11] .

Local wisdom is the cultural identity or personality of a nation that causes the nation to be able to absorb, even process culture that comes from outside or other nations into Wibowo's own character and abilities [12]. The cultural tourism characteristics of an area have a very decisive role in absorbing the impact of the tourism destinations of an area. Cultural tourism that has different characteristics than others is a superior value that can be used as a strength in attracting more tourists. Furthermore, Is tiawati [12] has the view that local wisdom is a way for people to behave and act in response to changes in the physical and cultural environment.

Local wisdom is a set of knowledge and good practices that come from previous generations and from experiences related to the environment and other communities belonging to a community in a place, which is used to properly and correctly solve the various problems and / or difficulties faced. Local wisdom comes from the values of customs, religious values and local culture which are naturally formed in a community group to adapt to the surrounding environment [8] . Zahrulian ingdyah [3] stated that the existence of a tourism industry based on local wisdom would at least :

1.Improve the economy of the surrounding community

2.Local revenue increases which will be beneficial for regional development

3.National income increases

4.The rise of culinary delights from tourist areas that still maintain local culture

5.The development of the snack food industry is a souvenir of tourists who can raise the image of tourism in Indonesia.

In tourism development, there are approaches that can be used and are based on local wisdom [11], namely:

1. participatory planning approach, involving all theoretical and practical elements in planning and developing the sustainability of tourism areas;

2. potential approaches and characteristics of the availability of cultural products that are capable of supporting sustainable management of tourist areas;

3. community empowerment approach, by providing opportunities for the surrounding community to develop personal and group abilities;

4. a regional approach, by looking at the linkage factor of the surrounding area to see the potential and planned in a balanced manner;

5. potential optimization approaches that can be integrated, taking into account the potential for culture and tourism that can be integrated

In addition, there are two basic approaches in combining local wisdom in tourism development [11], namely:

1. Buying products, by including elements of local wisdom in tourist products that can be enjoyed, such as souvenirs and culinary delights.

2. Buying experience, by combining elements of local wisdom in activities that can provide direct experience to tourists. This research will

\section{Methodology}

This study used a qualitative descriptive approach through interviews and literature study (library research) by utilizing the journals yan g according to research topics early. The focus of research in this paper is on the role of cultural communities in the development of halal 
tourism on Penyengat Island which is based on local wisdom . Data collection techniques in this study through interviews and documentation. The analytical method used in this research is interactive analysis with three components of analysis, namely data reduction, data presentation, and drawing conclusions [13].

\section{Finding and Discussion}

Penyengat Island is included in the administrative area of the Tanjungpinang City Government. Penyengat Island is a historical island that has an important position in the events of the rise and fall of the Malay Empire, which previously consisted of the Sultanates of Johor, Pahang, Siak and Lingga, especially in the southern part of the Malay Peninsula. This important role lasted for 120 years, since the establishment of the Riau Kingdom in 1722, until it was finally taken over completely by the Dutch in 1911. Various historical relics can still be seen today, such as the tombs of kings such as Raja Ali Haji, Mesjid Raya Sultan. Riau, which is made of egg white as an adhesive for buildings and a defense fort on the Hill. Apart from being the birthplace of Malay grammar (the basis of Malay grammar which was later called Indonesian), Penyengat Island is also a National Cultural Heritage Area through the decree of the Minister of Education and Culture No. / M / 2018 in 2018 and is regulated through the Regional Regulation of the City of Tanjungpinang Number 8 of 2018 concerning Management of Penyengat Island Cultural Tourism. This Ministerial Decree decides that the Penyengat Island Cultural Conservation Area becomes a National Rank Cultural Heritage Area, with a land area of 91.15 hectares and has 46 Cultural Heritage relics.

Penyengat Island is designated as a national cultural heritage because this island has two strategic values in the historical context of the western part of Indonesia. First, as an important part of the war period of the Kingdom of Riau against the Dutch (1782-1784) which ended with the death of King Haji Fisabilillah. Penyengat Island was the stronghold of Raja Haji during the war against the Dutch. Second, as the center of Malay civilization in the fields of language and culture. On Penyengat Island, Raja Ali Haji produced works in the form of the Bustan AlKatibin book, a book on Malay grammar which is the basis and source of the development of the Indonesian language, as well as a work entitled Gurindam Dua Belas, which contributed greatly to the development of the world of Malay and Indonesian literature[20].

The adoption of halal tourism on Penyengat Island certainly raises historical, cultural and religious tourism which is the prima donna of this region. The life of the local community is still thick with Malay culture, so the development of halal tourism on Penyengat Island must be based on local wisdom . Djakfar [14] stated that Mahathir Mohammad once proposed three tips for promoting halal tourism based on his observations in his own country, namely promoting and maintaining Islamic values and local wisdom; adopt the good things of the systems and standards dominated by Western civilization; and running the concept and marketoriented. There are several cultural communities that play a role in the development of halal tourism on Penyengat Island, including the Riau Islands Traditional Malay Institute (LAM), the Indera Sakti Foundation and the Aksi Bangun Negeri Foundation.

One of the organizations that is included in the stakeholders of the development of halal tourism destinations in Penyengat Island is the Riau Islands Traditional Malay Institute (LAM). The Riau Islands LAM aims to maintain, nurture and develop the indigenous values and culture of the Riau Archipelago Malay as an effort to enrich and strengthen the identity of the Malay community and are part of the national cultural treasures. Riau Islands LAM 
contributed to the development of halal tourism destinations in Penyengat Island through input and ideas conveyed through a forum for meeting of halal tourism stakeholders initiated by the Tanjungpinang City Culture and Tourism Office, as well as being involved in interactive discussions about "Tanjungpinang Halal Tourism Destinations" at RRI. Tanjungpinang together with ASITA, DPRD, MUI and the Tanjungpinang City Culture and Tourism Office. The Riau Islands LAM gave an idea about Tanjungpinang halal tourism, especially Penyengat Island, which should be built following the rules of Malay customs, especially in trade and community ethics including language speech , clothing, and communication patterns. This is in accordance with the main tasks of the Riau Islands LAM, namely:

1. Exploring, fostering and developing customs and culture in the Riau Islands Province that do not conflict with the teachings of Islam and Pancasila as the principles of the Republic of Indonesia.

2. Conducting efforts to find, collect and process materials and data on Malay Customs and Culture in the Riau Archipelago as long as it does not contradict Syara 'law and State

3. Instill and expand the knowledge of the Malay community on the Riau Archipelago Malay Customs and Culture in shaping the next generation.

4. Establish and endeavor harmonious and beneficial cooperation with community groups and the Government.

5. Provide opinions and suggestions whether requested or not to the Government in order to participate in driving the process of implementing Regional Development.

The Riau Islands LAM has also played a role in encouraging the Riau Islands Provincial Government to resume the construction of the Malay Language Monument (MBM) on Penyengat Island. The development of the MBM is a mandate of consensus 12, which was made between the Riau Islands LAM and the Riau Province LAM . The MBM development aims as a form of affirmation that Indonesian comes from Penyengat Island. Therefore, the construction is continued to show the identity and origin of the Unifying Language that originates from the Riau Islands Province [25]. MBM development is certainly going to be one tourist attraction Biting Island, to support the development of halal tourism by raising local knowledge as the main focus. This is in accordance with the basic needs of Muslim tourists based on the 2019 Mastercard-CrescentRating Global Muslim Travel Index, one of which is a travel experience related to local Muslim culture and identity. The same thing was also explained by Singsomboon [15], he found that in Thailand, local wisdom has been used to promote tourism thinking of creative tourism processes and to create conservation and development in various forms of projects. Using local wisdom to promote tourism through a creative tourism process in order to realize sustainable tourism development targeted at the community.

The Aksi Bangun Negeri Foundation contributed to the development of halal tourism destinations for Penyengat Island by preserving Malay cultural values by encouraging the movement to make Penyengat Island a world heritage. This foundation plays a role in the concept of building Penyengat Island as a platform for Malay and Islamic civilization. In an effort to become a UNESCO version of the world heritage, it is necessary to explore the special values that Penyengat Island has, including outstanding local value, outstanding national value, outstanding regional value, and outstanding international value. The Action Bangun Negeri Foundation is a forum that unites all elements in making Penyengat Island a world heritage. Efforts to strengthen support are carried out at every regional level to strengthen the outstanding value which is a requirement for determining the UNESCO version of world heritage. Efforts to make Penyengat Island a world heritage start at the local level in the Riau Islands. The Aksi Bangun Negeri Foundation is working on how Penyengat Island, which is sold as the main historical tourism product in the Riau Islands, is recognized by the Regional 
Government as a "regional icon" to strengthen the outstanding local value of Penyengat Island. Amir's research [16] concluded that the role of local government regulations in tourism development based on local wisdom is very strong. Local governments as policy providers, implementers and controllers must be able to inhibit the shift in the local wisdom of the community which characterizes a region. In fact, the local government in this case is unifying and upholding local wisdom in tourism development as the identity of an area in the midst of growing investment in the tourism sector through special regional regulations that regulate the existence, strengthening and preservation of local wisdom.

The strengthening of the outstanding regional value was carried out by involving support from the relatives of the Riau-Lingga Sultanate at the ASEAN level including Malaysia, Singapore and Brunei Darussalam. Furthermore, the Aksi Bangun Negeri Foundation seeks to consult with the Ministry of Education and Culture and the Ministry of Tourism to make Penyengat Island a "national icon", and to strengthen the outstanding national value of Penyengat Island[21]. The special and extraordinary values of Penyengat Island which are explored by the Action Bangun Negeri Foundation will strengthen the development of halal tourism in Penyengat Island. Branding Penyengat Island as a must-visit tourist destination will increase the popularity of this island's tourism to an international level. According to Urasevic [17] modern tourists demand authentic cultural experiences and unique local products can be seen as a response to the globalization process in tourism. In this sense, the increasing need for affirmation of local identity can actually be seen as a response to the trend of cultural globalization. Therefore, natural beauty is not only a major tourist attraction, but also a cultural attraction. Halal tourism may be most suitable for Muslim tourists, but it can also attract non-Muslim tourists if the destination provides a genuine uniqueness for non-Muslim tourists to experience [17]. The challenge is how to package its uniqueness from the original original destination so that it can provide the best value for non- Muslim tourists .

The Indera Sakti Island Penyengat Cultural Foundation, in its role as an accelerator for the development of the Penyengat Island halal tourism destination, has contributed to the preservation of Malay culture in terms of saving ancient Riau manuscripts, especially those written or printed on Penyengat Island. Another mission is as a center for cultural information, book authorship, and data services (for researchers). The ancient manuscripts owned by this foundation were obtained from the inheritance of the management's family, or purchased from the manuscript storage family, or given voluntarily by the manuscript storage family. The number of manuscripts currently recorded is 317 manuscripts (117 manuscripts, the rest are print). Of all these manuscripts, only about $40 \%$ have been studied comprehensively. Regarding manuscript maintenance, this foundation collaborates with ANRI and the National Museum for preservation; and with the Malaysian Library Board and the National University of Singapore for microfilm production. The manuscripts are kept at the Balai Maklumat, intended as an information center for Riau Malay culture. One of the major manuscripts written on Penyengat Island is Gurindam Dua Belas and the Malay grammar book Bustan al-Katibin .

Gurindam Dua Belas is one of the old Malay poems written by Raja Ali Haji, a writer and National Hero from Penyengat Island, which discusses issues of faith and Sufism, Islamic law, the pillars of Islam, character and morals and the concept of government. Gurindam Dua Belas consists of 12 articles, each of which contains advice and appeals that can touch the soul and awareness of the community. Gurindam Dua Belas is now one of the tour package options provided by Pokdarwis Penyengat Island for visiting tourists. The tour package is called the Gurindam Experience, where tourists are given the opportunity to learn how to read 
Gurindam Dua Belas like Malay writers. In addition, tourists will also study the Twelve Gurindam from its historical side, then explore by examining the implied meaning in it [22] .

Through the book Bustan al-Katibin which explains Malay grammar and a dictionary of languages entitled The Book of Language Knowledge, Raja Ali Haji has paved the way for systematic knowledge of Malay, which later evolved into Indonesian. The Bustan al-Katibin book includes an explanation of Malay grammar that adopts Arabic grammar, which contains an explanation of Malay letters derived from Arabic letters and an explanation of how to write them [23]. Penyengat Island is one of the areas where the use of the Malay language is very well maintained, polite, beautiful, and good, so that it is recognized by all Indonesians and linguistic experts, and is able to achieve high Malay language status, which is referred to by the Indonesian people and foreign nations when they communicating between them in the past [24].

Penyengat Island has a very rich heritage of traditions, customs, and Malay-Islamic manners. The commitment of the Penyengat Island community to nurture, nurture, develop, and apply the Malay-Islamic traditions, customs and manners will greatly determine the existence of these special values. Singsomboon [15] concluded in his research that the factors that influence the success of tourism development based on local wisdom include: having a strong community base, for example a community with an adequate production or economic system and harmony in the community; has fertile natural resources; have a leader who is able to foster trust; having a strong cultural base such as having a unique culture; local community participation; operate continuously; innovate and carry out creative tourism activities.

The potential of local wisdom also provides different opportunities in halal tourism, namely cultural tourism. Cultural tourism on Penyengat Island offers a different form of tourism, because it is rich in historical past glories, thick Malay customs, and strong religious life. Customs, cultures and religions of the community go hand in hand to form a local identity of the community that inspires people's life and interactions between the people in it. These three elements greatly support the development of halal tourism in Penyengat Island if it is carried out in a balanced and harmonious manner. The existence of local wisdom can be used as a social institution in managing tourism development, so that it still provides opportunities for local people to maintain the authenticity of customs and culture, even though they have interacted with outside communities. In his study, Yi-fong [18], discusses the socio-cultural effects of ecotourism, which integrates cultural revitalization, ecological conservation, and social development. Many cases in various parts of the world show that indigenous peoples have developed patterns in resource use and management practices that reflect detailed knowledge of local geography and ecosystems and contribute to the conservation of nature through their livelihood practices. For indigenous peoples, affirming their identity as a medium in preserving cultural identity and developing socio-economic potential is a way of survival in the modern industrial world. Environmental sustainability is inevitably related to the configuration of economic, social, cultural and political structures. With the growing strength of the tourism industry in the economic development strategy, the need to involve local communities in the process of sustainable tourism management is very much needed. 


\section{Conclusion}

The implementation of halal tourism on Penyengat Island raises historical, cultural and religious tourism which is the prima donna of this region. Cultural communities that play a role in the development of halal tourism on Penyengat Island, include the Riau Islands Traditional Malay Institute (LAM), the Indera Sakti Foundation and the Aksi Bangun Negeri Foundation. The Riau Islands LAM contributed through the idea that halal tourism should be built following the rules of Malay customs, especially in trade and community ethics including language speech, clothing, and communication patterns. The Aksi Bangun Negeri Foundation contributed to the effort to preserve the value of Malay culture by encouraging the movement to make Penyengat Island a world heritage by exploring the special values that Penyengat Island had, including outstanding local value, outstanding national value, outstanding regional value, and outstanding international value. The special and extraordinary values of Penyengat Island which the Yayasan Aksi Bangun Negeri have unearthed will strengthen the development of halal tourism on Penyengat Island. The Cultural Foundation of Indera Sakti Pulau Penyengat has contributed to the preservation of Malay culture in terms of saving ancient Riau manuscripts, especially those written or printed on Penyengat Island. One of the major manuscripts written on Penyengat Island is Gurindam Dua Belas, which discusses issues of faith and mysticism, Islamic law, the pillars of Islam, character and morals as well as governance concepts, and the book of Malay grammar Bustan al- Katibin, which paves the way for knowledge. systematic about the Malay language, which later evolved into Indonesian.

The suggestions given by this research are:

a. Increasing the role of cultural communities in creating tour packages containing travel experiences related to Malay culture and local Muslim identity

b. Optimizing the application of Malay culture and customs in the life of local communities

\section{References}

[1] Badan Pusat Statistik. Provinsi Kepulauan Riau Dalam Angka 2020

[2] Komariah N, Saepudin E, Yusup PM. Pengembangan Desa Wisata Berbasis Kearifan Lokal. J Pariwisata Pesona. 2018;3(2):158-74.

[3] Zahrulianingdyah A. Kuliner Sebagai Pendukung Industri Pariwisata Berbasis Kearifan Lokal. Teknobuga. 2018;6(1):1-9.

[4] Mahardika R. Strategi Pemasaran Wisata Halal. Mutawasith 3. 2020;65-86.

[5] Qodariyah L, Wahed S. Local Wisdom Based Tourism in Sharia Tourism Perpective (Tourism Concept Study of Sumenep Regency Madura). 2019;383(Icss):1141-5.

[6] Maturbongs EE, Lekatompessy RL. Kolaborasi Pentahelix dalam Pengembangan Pariwisata Berbasis Kearifan Lokal di Kabupaten Merauke. 2020;3(1):55-63.

[7] Destiana R. Analisis Peran Stakeholders Dalam Pengembangan Destinasi Pariwisata Halal di Pulau Penyengat Provinsi Kepulauan Riau. Universitas Diponegoro; 2020.

[8] Sugiyarto S, Amaruli RJ. Pengembangan Pariwisata Berbasis Budaya dan Kearifan Lokal. J Adm Bisnis. 2018;7(1):45.

[9] Battour M, Ismail MN. Halal tourism: Concepts, practises, challenges and future. Tour Manag Perspect [Internet]. 2016;19:150-4. Available from: http://dx.doi.org/10.1016/j.tmp.2015.12.008 
[10] Razzaq S, Hall CM, Prayag G. The capacity of New Zealand to accommodate the halal tourism market - Or not. Tour Manag Perspect [Internet]. 2016;18:92-7. Available from: http://dx.doi.org/10.1016/j.tmp.2016.01.008

[11] Tamaratika F, Rosyidie A. Inkorporasi Kearifan Lokal Dalam Pengembangan Kawasan Pariwisata Di Lingkungan Pantai. J Sosioteknologi. 2017;16(1):125-33.

[12] Christanti E. Implementasi Kebijakan Pariwisata Berdasarkan Kearifan Lokal (Studi Kasus Kabupaten Kotawaringin Barat). Ref J Ilmu Manaj dan Akunt. 2019; Volume 7 N.

[13] Sugiyono. Metode Penelitian Kuantitatif, Kualitatif dan R\&D. Bandung: Penerbit Alfabeta; 2011.

[14] M. Djakfar. Pariwisata Halal Perspektif Multidimensi Peta Jalan Menuju Pengembangan Akademik \& Industri Halal di Indonesia. Malang: UIN-Maliki Press; 2017.

[15] Singsomboon T. Tourism promotion and the use of local wisdom through creative tourism process. IJBTS Int J Bus Tour Appl Sci. 2014;2(2):32-7.

[16] Amir N. Development of Local Wisdom-Based Tourism. Adv Soc Sci Educ Humanit Res (ASSEHR), Vol 282. 2018;

[17] Bastaman A. Marketing Of Halal Tourism Based On Local Wisdom And Uniqueness. Proceeding Int Halal Tour Congr. 2017;

[18] Aswita. Local Wisdom Of Sabang Island Society (Aceh, Indonesia) In Building Ecological Intelligence To Support Sustainable Tourism. Geoj Tour Geosites. 2018;22.

[19] Y. E. Sahputra, "Ini Kiat Pemprov Kepri Tingkatkan Kunjungan Wisata pada 2020," TEMPO.CO, 12-Jan-2020. [Online]. Available: https://travel.tempo.co/read/1294282/inikiat-pemprov-kepri-tingkatkan-kunjungan-wisata-pada-2020/full\&view=ok.

[20] "Penyengat Ditetapkan jadi Cagar Budaya Nasional," Jantungmelayu.com, 18-Aug-2018. [Online]. Available: https://jantungmelayu.com/2018/08/penyengat-ditetapkan-jadi-cagarbudaya-nasional/.

[21] "Zaldy alqudsi: Bersama wujudkan Pulau penyengat menuju warisan Dunia," Wartakepri.co.id, 09-May-2018. [Online]. Available: https://wartakepri.co.id/2018/05/09/zaldy-alqudsi-bersama-wujudkan-pulau-penyengatmenuju-warisan-dunia/.

[22] "Filosofi Tangkal Hoaks dari Gurindam 12," Batamnews.co.id. [Online]. Available: https://www.batamnews.co.id/berita-55058-filosofi-tangkal-hoaks-dari-gurindam12.html.

[23] Jantungmelayu.com. [Online]. Available: https://jantungmelayu.com/2018/04/bustan-alkatibin-kitab-perkebunan-juru-tulis-karya-raja-ali-haji/.

[24] "Pulau Penyengat Indera Sakti Warisan Dunia," Batamtoday.com. [Online]. Available: http://m.batamtoday.com/berita59659-Pulau-Penyengat-Indera-Sakti-WarisanDunia.html.

[25] “Ada Mufakat 12 dengan LAM Riau, Abdul Razak Minta Monumen Bahasa Dilanjut," Hariankepri.com, 24-Apr-2020. [Online]. Available: https://www.hariankepri.com/adamufakat-12-dengan-lam-riau-abdul-razak-minta-monumen-bahasa-dilanjut/. [Accessed: 26-Mar-2021]. 